\author{
JOLANTA PASTERSKA \\ (D) https://orcid.org/0000-0003-0359-0264 \\ Uniwersytet Rzeszowski \\ Rzeszów

\section{Literackie figury domu w prozie Danuty Mostwin}

Literary figures of the home in Danuta Mostwin's prose

\begin{abstract}
The paper attempts to describe the literary figures of the home in Danuta Mostwin's seven-volume "Polish saga" (Dom starej lady, London 1958, Ameryko! Ameryko!, Warszawa 1981, Cień ksiedza Piotra, Warszawa 1985, Szmaragdowa zjawa, Warszawa 1988, Tajemnica znycieżonych, London 1992, Nie ma domu, Lublin 1996, Stysže, jak śpiewa Ameryka, London 1998). The biography of the author of Dom starej lady matches the biographies of multigenerational Polish families that had endured the partitions of Poland, wars, communism, and exile. This autobiographical feature become the substrate for most of Mostwin's novels. The deliberations, set in the context of philosophical and axiological as well as literary theory findings show the transformations in the creation of the figure of the home in these prose writings. The evolution of the imagery of the home ranges from an Arcadian home to an "anti-home", "home as an ark", and "home regained". This corresponds to Danuta Mostwin's philosophical position, as she considered this combination of values brought from her native country and the values acquired in the country where she settled as most optimal form of defending Polish identity in exile.
\end{abstract}

Keywords: Danuta Mostwin, emigration, home, symbolism

Człowiek od początku swojego istnienia pragnie miejsca, w którym czułby się bezpiecznie. Poszukuje przestrzeni osłaniającej jego prywatne życie. To jedna z podstawowych kulturowych aktywności jednostki. Martin Heidegger zamieszkiwanie w domu interpretuje jako konieczny warunek obecności jednostki w świecie albo wręcz sposób jej bytowania na Ziemi. Filozof stawia zatem znak równości pomiędzy „byciem” człowiekiem a zamieszkiwaniem (Heidegger 1974, 137-152). Budować, wznosić to tyle, co otaczać opieka. Taka interpretacja sytuuje dom jako przestrzeń szczególną, bowiem rozpostarta pomiędzy ziemią a niebem, zbliża człowieka do Stwórcy. W tym 
kontekście budowanie domu jest w pomniejszonej skali swoistym powtórzeniem aktu stworzenia świata, to kreowanie własnego mikrokosmosu. Sam obrzęd stwarzania/budowania/wznoszenia, za Mircea Eliadem, uświęca przestrzeń, czyni ją miejscem sacrum (Eliade 1992, 27-34). Człowiek przywiązuje wagę do tego w jakim miejscu się osiedli i jaki zbuduje dom, bowiem bierze na siebie odpowiedzialność za „kreację przestrzeni wybranej na miejsce zamieszkania" (Trojanowska 2008, 19). Osiedlenie i budowanie to działania związane $\mathrm{z}$ takim a nie innym wyborem egzystencjalnym, ,wyborem «świata», który «stwarzając» gotowi jesteśmy przyjąć” (Eliade 1970, 72).

Historia XX wieku naznaczona przymusowym porzuceniem domu i, dłużej lub krócej, odczuwaną bezdomnością jeszcze mocniej akcentuje marzenie jednostki o własnym „gnieździe”. W wyniku kataklizmów wojennych i zmian politycznych dom nabierał wówczas szczególnego znaczenia, wiązał się ze stratą i próbami jego odbudowania, często w obcym miejscu, w obcej przestrzeni. Wraz z naruszeniem tej przestrzeni pojawiło się rewaloryzowanie wartości, tradycji, religii, wspólnotowości. Nastąpił zatem swego rodzaju aksjologiczny rozstrój.

W literaturze kategoria ta nie sprowadza się jedynie do znaczenia symbolicznego. Budowanie przez homo domesticusa własnej siedziby utożsamiane jest także - jak przekonuje Anna Legeżyńska - ze strukturą myślenia. Dom nie tylko „osobliwie istnieje, lecz również osobliwie znaczy” - powiada badaczka (Legeżyńska 1996, 7-8). Uczona dowodzi, że „potrzeba zachowania korzeni lub odnalezienia tożsamości, pojawia się zawsze wraz z tęsknotą o utraconym domu" (Legeżyńska 1996, 19). Wówczas na obraz realnego braku domu nakłada się ten oniryczny, do którego, cytując Bachelarda, „wiernie powracamy zasnąwszy” (Bachelard 1975, 301). W ten sposób rodza się wspólne ludziom archetypiczne wyobrażenia omawianej figury jako schronienia, oazy intymności, powrotu do beztroskiego dzieciństwa. Archetyp domu to Matka uosabiająca macierzyńskie ciepło (Bachelard przyrównuje bezpieczny, zamknięty budynek do łona matki (1975, 324-324)) i Ojciec przywódca rodu, gwarant bezpieczeństwa.

Człowiek nosi w sobie swoje własne wspomnienie rodzinnego gniazda. To nie tylko budynek, mury, ale przede wszystkim szczegóły, przedmioty, dźwięki, kolory, zapachy, które działają na pamięć i wyobraźnię jednostki, inspirują niczym ów proustowski smak magdalenki (Gołaszewska 1997). Trafnie scharakteryzował te doznania Marian Kisiel, który pisze, że „uwodzi nie całość, ale część - drobiazg, rzecz, zapach. To, co idiosynkratyczne, a nie wspólnotowe. Domy skrywają wiele tajemnic, każdy z nas ukrył w nim 
przynajmniej jedną własną” (Kisiel 2019, 481). To doświadczenie jednostkowe domu w perspektywie temporalnej obrasta w mit, staje się - powtórzę za wspomnianym wyżej badaczem - opowieścią uświęcona, „gdzie to, czego już nie ma, co prawdopodobnie było, a teraz istnieje tylko w narracji osoby pamiętającej, staje się zasadniczą częścią mojego «ja»” (Kisiel 2019, 481).

Z takiej perspektywy chciałabym przyjrzeć się prozie Danuty Mostwin, która w siedmiotomowej „sadze polskiej” (Dom starej lady, Londyn 1958; Ameryko! Ameryko!, Warszawa 1981; Cień kesięza Piotra, Warszawa 1985; Szmaragdowa zjawa, Warszawa 1988; Tajemnica zuycieżonych, Londyn 1992; Nie ma domu, Lublin 1996; Stysze, jak spiewa Ameryka, Londyn 1998) akcentuje rolę rodzinnego domu - miejsca niszczonego przez zaborców, powstania, wojny, komunizm, ale nigdy niezniszczonego, odradzającego się w emigracyjnych realiach niczym mityczny Feniks z popiołów.

W biografii Danuty Mostwin oraz w jej wspomnieniach powtarzają się trzy lokacje związane z rodzinnym domem: Kraśnik, Lublin i Warszawa. Do nich po latach dołączy amerykańskie Baltimore. Te miejsca odnajdujemy także w jej powieściach, stają się ważną przestrzenią autobiograficzną. Wpisane w realia geograficzne i historyczne ulegaja stopniowo procesom mityzacji, ale także poddane zostają zabiegom fikcjonalnym. W twórczości autorki Oliwii dom tożsamy jest z rodem. Mimo zmieniających się uwarunkowań politycznych kraju oraz sytuacji materialnej rodziny (rodzinna opowieść rozpoczyna się bowiem historią prapradziadków narratorki od roku 1863 i jest prowadzona do lat dziewięćdziesiątych $\mathrm{XX}$ wieku) pewne elementy tego opisu są stałe. Znaczenie to nie ulega zmianie (Dutka 2008, 66).

Figura domu w sadze Danuty Mostwin pełni odmienną funkcję niż ta, wywodząca się z romantyzmu zawarta w maksymie: „szczęścia w domu nie znalazł, bo go nie było w ojczyźnie", bowiem podstawą egzystencji bohaterów jest właśnie gniazdo rodzinne. Praca (w pozytywistycznym rozumieniu) i pełne wyrzeczenia życie podporządkowane zostaje realizacji marzenia o własnym miejscu. Pradziadek narratorki, Jan Zdziechowski, obiecuje narzeczonej Paulinie Kulczybównie:

dom ci taki wybuduję (...) jakiego nikt jeszcze nie miał. Dwór to będzie. Najpiękniejszy z wszystkich dworów w okolicy. Modrzewiowy będzie dom, osikowy gont, a podłogi wszystkie z dębu (...). W każdym [pokoju] wstawię wielki piec (...) z kolorowych kafli. (...) Klomb będzie jeden wielki, ogrodzony (...) lipami (Mostwin 2004, 21). 
Dom jako miejsce zorganizowane, uporządkowane, ogrodzone jest znakiem porządku i ładu. Przeciwstawiany jest chaosowi świata. Zwróćmy uwagę, że szczególne miejsce w cytowanym opisie zajmuje opis dachu interpretowanego jako niebo oraz pieca - metafory ogniska domowego. Wyobrażenie rodzinnego gniazda Zdziechowskich jest także silnie powiązane z symbolika domu polskiego, szlacheckiego, rodem z Mickiewiczowskiego Soplicowa. W latach rozbiorów siedziba taka była postrzegana jako azyl duchowy i ostoja polskości. Ta mocno nacechowana relacja dom - ojczyzna w prozie Mostwin wybrzmiewa szczególnie. W historię rodu narratorki silnie wpisuje się działalność księdza Ściegiennego, ojca chrzestnego prapradziadka narratorki, alter ego pisarki, udział brata prababki w rewolucji październikowej, wreszcie wstapienie w szeregi Armii Krajowej samej narratorki. W tym kontekście mamy tu do czynienia $\mathrm{z}$ mocno zakorzeniona w świadomości Polaków figurą domu jako miejsca kultywowania tożsamości narodowej. Jednak jak wolno sądzić, nie tylko takie ujęcie tego motywu zajmuje Danutę Mostwin. W jej prozie o wiele więcej miejsca poświęcono jego znaczeniu dla krystalizacji rodziny i kształtowania postaw jej członków. Dlatego narracja całej sagi to swoista wędrówka w czasie od kraśnickiego domostwa praprababki Katarzyny i lubelskiego mieszkania Pauliny do domu jej praprawnuczki Bogi w Monumental City (Boltimore). Nestorka rodu - Paulina nie doczekała się wyśnionego i obiecanego przez męża dworku: „[Jan] nie wybudował [domu]. Od czterech lat mieszkali w dawnym domu kraśnickiego organisty. Dom ten niski, słomą kryty, nieszczelny już był, wilgotny” (Mostwin 2004, 21).

Dla rodziny Kulczybów dom był najważniejszy. Utyskujący na opieszałość i lenistwo zięcia, senior rodu powtarzał córce:

pamiętaj, pierwsze siedło, drugie jedło. (...) Człowiek bez gruntu, bez tego domu swego, to jak to drzewo, co widzisz w lesie ścięte, jeszcze te gałązki w listkach, a już uschłe, ani się rozwinie, ani przetrwa. Najpierw w siele siedź, a potem, o innych sprawach radź (Mostwin 2004, 22).

To ważne przykazanie, które wyniosła z domu ojca jego córka, istotne było z dwóch powodów. Po pierwsze, dom gwarantował trwałość rodu, był swego rodzaju scheda pochodzenia. Po wtóre, w tradycji mistyków uważano go za „żeński aspekt Wszechświata (podobnie jak ogród) oraz za siedlisko duszy" (Kopaliński 1990, 69). Wpisywał się tym samym w sferę wpływów kobiecych. Dla wszystkich bohaterek prozy Mostwin walka o to własne 
miejsce, oswojona przestrzeń, będzie priorytetem. Budowanie domu to kreacja miejsca. Przypomnijmy, że wedle Kwiryny Handke jest on „najbardziej podstawowym synonimem miejsca” (Handke 1997, 29). W ten sposób dzięki wznoszeniu swojej siedziby zostaje wydzielony fragment przestrzeni należącej „dotąd do świata”, jest on niejako „udomowiony”. Jeśli Yi-Fu Tuan twierdzi, że „miejsce to bezpieczeństwo, przestrzeń to wolność” (Tuan 1987, 13), to w przypadku budowania domu owa zawłaszczona przestrzeń staje się miejscem. Opozycja miejsce - przestrzeń (dom - świat) pozostaje, ale jest bardziej widoczna. Człowiek zmienia perspektywę widzenia świata, patrzy na niego z domu, z wewnątrz, dlatego ważne jest, jakie to domostwo będzie, jakie będą jego „fundamenty”. Paulina sama wybuduje dom/kamienicę w Lublinie, do którego będą powracać jej dzieci i wnuki. Katarzyna swojej pierworodnej zaszczepiła umiejętność dbania o rodzinny klimat, następnym dwu pokoleniom dom rodzinny będzie się łączył w myślach z ciepłem, przytulnością i zapachami. Seniorka rodu kojarzyła się dzieciom, wnukom i prawnukom jako osoba przywiązana do czynności domowych, która wypracowała własne przepisy potraw i kompozycje przypraw. Wspomnienie jej domostwa przywoływało w pamięci spiżarnię wypełniona przetworami oraz doznania smakowe i zapachowe:

Obraz anyżku z wielkich glinianych mis, zapach kiełbas i szynek, cierpki zapach marynat w stojących rzędem na półkach słoi pełnych kiszonych ogórków, borówek, zielonych pomidorów, śledzi, zapach zalanych tłuszczem smażonych i pieczonych mięs, grzybów, korzeni (Mostwin 2004, 18).

W innym miejscu narracja koncentruje się na szczegółowych opisach przygotowań do świąt. Mieszkanie wypełnia wówczas zapach wanilii, araku, parzonych migdałów. Paulina w wianie od matki Katarzyny otrzymuje przepisy na mazurki, wielkanocne baby, przekładaniec ze śliwkami oraz porady, jak sklarować masło albo gotować miód na nalewkę.

Królestwem Mostwinowych bohaterek pozostaje kuchnia. Freud odczytywał ja w kontekście marzeń sennych jako symbol matki. To przestrzeń szczególnie nacechowana, powszechnie uważana za serce domu, ale i ośrodek decyzyjny (jest wszakże miejscem rodzinnych narad dotyczących udziału w konspiracji albo opuszczenia na stałe ojczyzny). Zwróćmy uwagę, że przytoczone w cytowanym fragmencie wyobrażenia wizualne, smakowe i zapachowe są szczególnym portretem pamięciowym Katarzyny, obrazem, który przetrwał w kolejnych pokoleniach i automatycznie niejako wywołuje 
u prawnuczki wspomnienie losów jej rodziny, sięga przeszłości zakorzenionej w XIX wieku. W ten sposób tworzy się mit domu jako gniazda, w całej sadze jest on ważnym budulcem rodzinnej opowieści. Będzie ów mit powracał w obrazie domu prababki w Kraśniku, babki Pauliny w Lublinie, rodziców na Saskiej Kępie w Warszawie (Stępień 2000, 41). Umiejscowiony w centrum narracji zapewnia bohaterom sagi bezpieczeństwo, spokój, szacunek i oczywiście - miłość. Kolejne pokolenia Kulczybów dzięki ciężkiej pracy i nauce bogaciły się, budowały coraz nowocześniejsze domostwa, ale tego pierwszego siedliska utożsamianego z praźródłem pochodzenia, mimo że po latach stało się ciasnym, pozbawionym wygód miejscem, nikt z potomków rodu nie odważył się wyburzyć.

Domek jest wiekowy, chyba go jeszcze stawiał dziadek Dominik. Mury solidne, średniowieczna forteca (...) przysiadł mocno na ulicy, wszczepił się, trwal (Mostwin 2005, 24).

Powrót do lubelskiego domu uruchamia w pamięci matki Bogi wspomnienia osób, które w nim mieszkały, ale i tych, które znajdowały w nim schronienie. Przywołuje z przeszłości także obrazy zwyczajów kultywowanych przez rodzinę. Autorka Ameryko! Ameryko! z niezwykłą starannością odtwarza tradycje polskiego domu. Pisze o zwyczajach związanych z weselem (kupno materiału na suknię, wybór jej fasonu, zakup bielizny osobistej i pościeli, zaślubiny w kościele, powitanie młodej pary chlebem i sola) i szczegółowo odtwarza wystrój pomieszczeń (stół przykryty białą serweta, chłodnik w porcelanowej wazie, na ścianach poczerniałe obrazy, pod nimi wysiedziane fotele, kanapa). W tym znaczeniu figura domu w opowieści Danuty Mostwin pełni funkcję (za Pierre'em Nora) miejsc pamięci, które postrzegamy nie tyle jako konkretne punkty topograficzne, ale przede wszystkim jako znaki tożsamości samego autora (Zalewski 1996, 45), a także wytwory kulturowe, które są zakodowane w świadomości zbiorowej jako własność danej wspólnoty (Nora 2009, 4-12).

W trzech ostatnich częściach sagi (Nie ma domu, Dom starej lady i Ameryko! Ameryko.) dom został wykreowany jako symbol utraty albo wręcz jego zaprzeczenie - antydom (Trojanowska 2008, 87). W powieści Nie ma domu tytułową sekwencję bohaterka powtarza wielokrotnie niczym mantrę. Dom przy ulicy Francuskiej w Warszawie został roztrzaskany przez spadające radzieckie (nie niemieckie!) pociski: 
Odgłos dział coraz wyraźniejszy. Nagle huk! Blisko. To w nas. Dom szarpnął się. Zakołysał. Osiadł. Tynk w oczach, w gardle. Krzyk. Na pomoc! Ratunku! (Mostwin 2005, 15).

Personifikacja domu, który „,czuje”, „,szarpnął się”, ,zakołysał się”, wzywa ratunku, podkreśla silny z nim związek jego mieszkańców. Oszczędność słowa, zastosowana zgoła Lechoniowa metaforyka (zob. liryk Póki my ṡyjemy) oddaje tragizm chwili. Matka narratorki Irena nie poddaje się i w zrujnowanej stolicy, na Saskiej Kępie, wynajduje mieszkanie, do którego znosi ocalałe z bombardowania sprzęty, by stworzyć namiastkę dawnego domu. Boga z podziwem i wdzięcznością opisuje poczynania rodzicielki:

Wiedziałam, już coś kombinuje, tworzy, organizuje na tych minach, wśród płaskich mogiłek, pomaga kiełkującemu życiu niezłamana okupacją, bije z niej nowy gejzer energii (...). Wchodzimy do dużego narożnego pokoju (...). Parkiet. Dywan! Rozpoznaję meble uratowane i przeniesione tu z naszego dawnego mieszkania: wielkie biurko ojca, fotele, tapczan. Ile wysiłku musiało ją kosztować wyszukanie tej wyspy niewiarygodnego luksusu w zburzonym mieście (...). Ocalałe mieszkanie było jak gniazdo uwite $\mathrm{w}$ dziupli uderzonej przez piorun. Uschła już ścięta korona i żywica zastyga na ranach kory, ale życzliwe wnętrze jeszcze osłania i chroni (...). Kuchnia tętni życiem (Mostwin 2005, 45, 47).

Jednak wysiłek budowania własnego domu od nowa w powojennej ojczyźnie zakończy się niepowodzeniem. Na przeszkodzie stanie komunistyczna władza uosobiona w postaci siła dokwaterowanego sublokatora prostackiego Bielika, konfidenta, donosiciela i pijaka. Dom jako schronienie, jako przestrzeń własna i bezpieczna przestał istnieć.

Miejsce domu w państwie totalitarnym zajmuje antydom - zaprzeczenie wszystkich po kolei cech Gniazda - bezpiecznego schronienia. W świecie opanowanym przez fałszywe wartości nie sposób już bowiem czuć się pewnie i bezpiecznie (Trojanowska 2008, 87).

Niepokój rodziny Bogi budzi zgraja rozpychających się w mieście chamskich Bielików i szpiegujących dla nowej władzy donosicieli. „Dom nie istnieje, nie jest możliwa jego kreacja w zniewolonym przez kłamstwo i strach świecie" (Trojanowska 2008, 87).

Narratorka i potomkini rodu wraz z mężem i matką opuszczają to, co przestało być domem, w znaczeniu szerszym emigrują nie tylko z konkret- 
nego miejsca zamieszkania, ale z ojczyzny. Na obczyźnie stery budowania gniazda przejmuje najmłodsza przedstawicielka rodu - Boga. W Londynie kupuje dom na The Park - adres jest ważny, bo umiejscawia i stabilizuje egzystencję na emigracji. Mostwin owo pragnienie posiadania własnego domu opisuje tak:

żeby można było mówić głośno, do woli, biegać po własnych schodach, patrzeć przez swoje okna na swój kawałek ogródka (...). To nieważne, że świat naokoło nie był takim, do jakiego przywykliśmy od dzieciństwa! Po przekroczeniu progów naszego domu odnajdziemy go i odnajdziemy siebie (Mostwin 2006, 10).

W sytuacji wyobcowania i poczucia bezdomności aktywa własnego miejsca zamieszkania nie sprowadzają się jedynie do kupna budynku, ale polegaja też na kreowaniu domu. Dom na emigracji ma bowiem spełniać rolę depozytariusza wartości i tradycji rodzinnych, ale także ma być strażnikiem polskości. Zatem obok próby modernizacji starej angielskiej willi na wzór polskiego dworku, którą podejmują nowi właściciele, zostaja wprowadzone/odtworzone obrzędy i zwyczaje, jakie były kultywowane w kraśnickim i lubelskim domu przodków. Mostwin w powieściach, których akcja dzieje się na emigracji, zmienia model opisu. Dom-gniazdo zostaje zastapiony wzorcem domu-arki. Narratorka sagi zabiera bowiem w podróż w nieznane wszystko to, co najcenniejsze: rodziców, własne dzieci i pamiątki po przodkach. Dom-arka ma chronić przed zalewem obcego świata, stać się ostoją rodziny i polskości. Nic zatem dziwnego, że pierwszym posiłkiem podanym we własnym londyńskim domu były:

polskie kluski kartoflane i zdobyte mięso, bo przecież był to okres kartek żywnościowych i pieczeń stanowiła atrakcję. Rozrzewniłam się, patrząc, jak powoli na twarzach głodomorów rozlewał się błogi wyraz nasyconego zadowolenia (Mostwin 2006, 13).

Podjęte próby zadomowienia się w Londynie nie powiodły się. Ów angielski dom nie dał się „spolszczyć”, a jego właściciele nie stali się zasymilowanymi Brytyjczykami. Po kilkuletnim pobycie w Anglii czuli się „rozżaleni odepchnięciem, przypominaniem, że są zawadzającymi cudzoziemcami” (Mostwin 1988, 12). W poszukiwaniu nowej siedziby odbyli kolejną podróż, w Ameryce zakorzenili się dzięki wykształconemu przez lata tułaczki przekonaniu, że dom „mamy (...). Nosimy go w sobie, najprawdziwszy i jedyny. 
Co nas obchodza przestrzenie, kraje, granice!” (Mostwin 2006, 206). To wykreowany w opowieści Mostwin obraz arche-domu, prawdziwego rodzinnego domu, którego nie można zniszczyć ani zamienić na coś innego, na jakiś nie-dom (Sawicka 1997, 47).

Taki obraz domu-arki, jest charakterystyczny dla prozy Mostwin, w której autorka opisuje pierwszy etap życia na emigracji. Natomiast w kolejnych utworach, poświęconych już stopniowej aklimatyzacji i akulturacji, kreacja ta ulega zmianie. Dom przestaje być zamkniętą arką, staje się przestrzenią otwartą:

Dopiero wtedy Żuławscy i Baskowie (...) zdecydowali się na pozostanie w Baltimore, zaczęli przyglądać się miastu. Było rozległe, jakby rozlane, ze śladami tu i ówdzie świetności (Mostwin 1998, 15).

Sagę kończy portret wielopokoleniowej rodziny narratorki, która kupuje własny dom-farmę nieopodal Monumetal City. W krajobrazie kukurydzianych pól, w otoczeniu lasów pełnych grzybów, sadu i malinowego ogrodu bohaterowie odbudowują ze zgliszcz nowy - na poły polski, na poły amerykański dom. Powieściowa Boga zaczyna stopniowo chłonąć nowy kraj, wsłuchuje się weń słowami wiersza Walta Whitmana: „Słyszę, jak śpiewa Ameryka, przeróżne pieśni słyszę / Śpiewają robotnicy, każdy pieśń swoja nuci / tak, jak być powinno, radosną, silną" (Mostwin 1998, 5).

Bohaterowie sagi przyjmuja zatem na emigracji promowana przez Mostwin postawę „trzeciej wartości” (Mostwin 1995). Budowanie tożsamości rozpoczyna się i krystalizuje w rodzinie, żadne „legendy historyczne, śmierć młodych ludzi w powstaniu” (Stasiuk 2019, 31), „klecenie pieśni o bohaterach na zatratę nowych pokoleń" (Mostwin 2004, 342) tego nie zastapią. Mocne korzenie rodowe są gwarantem, że żyjąc w ciężkich i wymagających czasach, można zachować swoją tożsamość. Tak zostaje wykreowany obraz emigracyjnego domostwa, który można nazwać domem odzyskanym. To gmach odbudowany na wartościach wyniesionych z ojczyzny i wartościach przyswojonych na obczyźnie.

Opowieść Danuty Mostwin o własnym siedlisku to historia nie tylko jednej, wspartej pamięcią własną, historycznymi źródłami i dokumentami, rodziny. Można te zapisy traktować jako pars pro toto (Kochańczyk 1992, 4) dziejów pokolenia pisarki. W tym kontekście wypada interpretować podtytuł

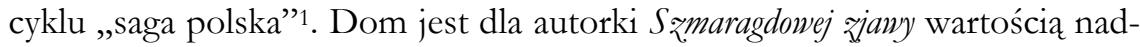

1 Sagę Mostwin można odczytywać w kontekście kroniki realnych topograficznie, istniejących miejsc i żyjących ludzi. Organistówka, w której po ślubie z Janem zamieszkała Paulina, 
rzędną. Utożsamia, zatem ponadczasową i ponadpokoleniową tęsknotę człowieka za uporządkowanym, scalonym światem.

\section{Bibliografia}

Bachelard G.,1975, Wyobraźnia poetycka. Wybór pism., przeł. Chudak H. i in., przed. Błoński J., Warszawa.

Buczyńska-Garewicz H., 2006, Szczeście domu, w: tejże, Miejsca, strony, okolice: przyczynek do fenomenologii przestrzeni, Kraków.

Dutka E., 2008, Okolice nie tylko geograficæne. O twórczości Andræeja Kuśniewicza, Katowice.

Eliade M., 1970, Sacrum, mit, historia, przeł. Tatarkiewicz A., Warszawa.

Eliade M., 1992, Świat, miasto, dom, w: tegoż, Okultyzm, czary, mody kulturalne. Eseje, przeł. Kania I., Kraków.

Gołaszewska M., 1997, Estetyka pięciu zmystów, Warszawa.

Handke K., 1997, Rozważania i analizy jezykoznawcze, Warszawa.

Heidegger M., 1974, Budować, miesžkać, myślé, ,,Teksty”, nr 6.

Holmgrem B., 2005, W domu Sienkiewicza, w: Filipowicz H., Karcz A., Trojanowska T., red., Polonistyka po amerykańsku. Badania nad literatura polska w Ameryce Pótnocnej (1990-2005), Warszawa.

Karwowska B.,2013, Druga płé́ na wygnaniu. Doświadcz̧enie migracyjne w opowieśsi powojennych pisarek polskich, Kraków.

Kisiel M., 2019, Dom. O wierszu Adama Czerniawskiego, w: Pasterska J., Ożóg Z., red., Dyskursy pogranicza. Wektory literatury. Prace ofiarowane profesorowi Stanisławowi Uliaszowi, Rzeszów.

Kochańczyk A., 1992, Stowo o Danucie Mostwin, „Tydzień Polski”, nr 45.

Kopaliński W., 1990, Stownik symboli, Warszawa.

Legeżyńska A., 1996, Dom i poetycka bezdomność w liryce wspótczesnej, Warszawa.

Levine M.G, 2005, Bezdomność w literaturze wojennej. Typy obrazowania, w: Filipowicz H., Karcz A., Trojanowska T., red., Polonistyka po amerykańsku. Badania nad literatura polska w Ameryce Pótnocnej (1990-2005), Warszawa.

Mostwin D., 1958, Dom starej lady, Londyn.

Mostwin D., 1981, Ameryko! Ameryko!, Warszawa.

Mostwin D., 1985, Cień księdza Piotra, Warszawa.

Mostwin D., 1988, Szmaragdowa zjawa, Warszawa.

Mostwin D., 1995, Trzecia wartość. Wykorzenienie i tożsamość, Lublin.

Mostwin D., 1996, Nie ma domu, Lublin.

stoi w Kraśniku do dzisiaj, tak jak kościół pod wezwaniem Wniebowzięcia Najświętszej Maryi Panny. W miejscu domu przy Narutowicza 55 w Lublinie, gdzie po powstaniu schroniła się Danuta Mostwin, stoi dziś nowoczesny budynek biurowo-usługowy. Pod warszawskim adresem Francuska 12 jest obecnie blok mieszkalny. Dom przy The Park 29 w Londynie (przypomnę, że tam toczy się akcja Domu starej lady) także istniał. W odtworzeniu polskich realiów zapewne pomocną była Monografia historyczna, społecそna i gospodarcza powiatu janowskiego opracowana przez Wacława Stefana Flisińskiego, z którym autorka utrzymywała znajomość. 
Mostwin D., 1998, Stysz̨e, jak śpiewa Ameryka, Londyn.

Nora P., 2009, Między pamięciq a historiq: Les Lieux de memoire, przeł. Mościcki P., „Tytuł Roboczy: Archiwum", nr 2.

Sawicka J., 1997, W keregu światta lampy. Dom wedtug Michaiła Buthakowa, w: Dąbek-Wirgowa T., Makowiecki A.Z., red., Obraz domu w kulturach stowiańskich, Kraków.

Sławek T., 2013, Mapa domu, w: Sławek T., Kunce A., Kadłubek Z., red., Oikologia. Nauka o domu, Katowice.

Stasiuk A., 2019, Polacy to bisterycy. Wywiad Jarka Szubrychta z. Andrzejem Stasiukiem, „Gazeta Wyborcza", http://wiez.com.pl/2019/06/11/andrzej-stasiuk-polacy-to-histerycy [dostęp: 24.06.2019].

Stępień M., 2000, Trzecia wartość. O twórczości Danuty Mostwin, Kraków.

Trojanowska U., 2008, Archetyp domu w dwudziestowiecznej literaturze rosyjskiej, Kraków.

Tuan Yi-Fu, 1987, Przestrzeń i miejsce, przeł. Morawińska A., Warszawa.

Zalewski M., 1996, Formy pamięci. O pržedstawianiu prz̧esz̧łości w polskiej literaturze współczesnej, Warszawa.

Jolanta Pasterska - prof. dr hab., Instytut Polonistyki i Dziennikarstwa, Uniwersytet Rzeszowski, Rzeszów, Polska.

Literaturoznawca zatrudniona w Zakładzie Teorii i Antropologii Literatury Uniwersytetu Rzeszowskiego, kierownik Pracowni Badań i Dokumentacji Kultury Literackiej, zastępczyni redaktora naczelnego pisma "Tematy i Konteksty”. Autorka książek: Świat według Tyrmanda. Przewodnik po prozie fabularnej Leopolda Tyrmanda (Rzeszów 1999); "Lepszy Polak"? Obrazy emigrantów w prozie polskiej po 1945 roku (Rzeszów 2008). Emigrantki, nomadki, wagabundki. Kobiece narracje (e)migracyjne (Rzeszów 2015); Wygnanie i mit. Szkice o pisarzach (e)migracyjnych (Rzeszów 2019). Pod jej redakcją ukazuje się seria Z Archiwum Pisarza. Redaktorka i współredaktorka numerów tematycznych pisma "Tematy i Konteksty": Wielka Emigracja - Druga Emigracja Niepodległościowa (E)migracja końca XX wieku (2011, nr 2); Proza nowa i najnowsza (2015, nr 5); Literatura polska 1918-2018. Narracje, dyskursy, dzieła (2018, nr 8) oraz 33 innych monografii wieloautorskich. Przedmiotem zainteresowań badawczych są: polska literatura współczesna - zwłaszcza polska proza emigracyjna i migracyjna, polska proza najnowsza, problemy tożsamości w literaturze i kulturze przełomu XX i XXI wieku.

Kontakt: jolapas@ur.edu.pl 